\title{
The gas membrane sensor (GMS) method: a new analytical approach for real-time gas concentration measurements in volcanic lakes
}

\author{
MARTIN ZIMMER ${ }^{1 *}$, FRANCO TASSI ${ }^{2,3}$, ORLANDO VASELLI $^{2,3}$, \\ CHRISTIAN KUJAWA ${ }^{1}$, JACOPO CABASSI ${ }^{2,3}$ \& JOERG ERZINGER ${ }^{1}$ \\ ${ }^{1}$ GFZ German Research Centre for Geosciences, Telegrafenberg, \\ 14473 Potsdam, Germany \\ ${ }^{2}$ Department of Earth Sciences, Via G. La Pira 4, 50121 Florence, Italy \\ ${ }^{3}$ CNR-IGG Institute of Geosciences and Earth Resources, Via G. La Pira 4, \\ 50121 Florence, Italy \\ *Corresponding author (e-mail: weihei@gfz-potsdam.de)
}

\begin{abstract}
The primary goal of this study was to apply an innovative analytical method based on a gas membrane sensor (GMS) to quantify the concentrations of $\mathrm{CO}_{2}$ and $\mathrm{CH}_{4}$ gas in water columns from volcanic lakes. For this purpose, dissolved $\mathrm{CO}_{2}$ and $\mathrm{CH}_{4}$ from the Monticchio Grande and Piccolo (Mt Vulture, Italy) and Pavin (Massif Central, France) lakes, characterized by depths of 35, 38 and $92 \mathrm{~m}$, respectively, were measured using two different approaches: GMS and SH (single hose), the latter being an independent conventional method.

The $\mathrm{CO}_{2}$ and $\mathrm{CH}_{4}$ concentrations recorded via the GMS and $\mathrm{SH}$ techniques were within the analytical errors of the two methods. These test measurements demonstrated that the GMS method can be successfully used to produce highly accurate in situ measurements of dissolved gas composition along the vertical profiles of lakes.
\end{abstract}

Volcanic lakes are commonly found in both dormant and recently active volcanic systems (Simkin \& Sieber 1994; Delmelle \& Bernard 2000). According to the classification proposed by Pasternack \& Varekamp (1997), chemical and physical features of the water allow us to clearly distinguish two main volcanic lake categories: (1) highactivity lakes, consisting of acidic-to-hyperacidic lakes strongly affected by inputs of volcanic fluids; and (2) low-activity lakes, characterized by relatively low salinity and almost neutral $\mathrm{pH}$, being located in systems with a low-to-moderate degassing rate of deep-originated fluids. Lakes pertaining to the latter group can be meromictic and show permanent dissolved gas reservoirs (Tassi \& Rouwet 2014 and references therein). In this environment, the possible occurrence of vertical water mixing (rollover events) related to exo- or endogenic processes, e.g. landslides, earthquakes or increasing volcanic activity, may cause the sudden outburst of huge amounts of gases (limnic eruptions; Sabroux et al. 1987; Kusakabe 1996; Halbwachs et al. 2004; Kusakabe et al. 2008). These dramatic events represent a serious hazard, as demonstrated by the two disasters that occurred at Monoun and Nyos lakes (Cameroon) in 1984 and 1986, respectively
(Kling et al. 1987; Sigurdsson et al. 1987). The origin of non-atmospheric gases found in volcanic lakes, basically consisting of $\mathrm{CO}_{2}$ and $\mathrm{CH}_{4}$, is mainly related to: (1) fluid contribution from underlying volcanic systems; and (2) microbial activity (Tassi \& Rouwet 2014). The physicochemical evolution in time of dissolved gas reservoirs depends on both biogenic and geogenic inputs (Cabassi et al. 2014). The artificial degassing of bottom waters, a method successfully applied at Nyos and Monoun lakes (e.g. Kling et al. 2005), is considered particularly efficient to mitigate the risk of limnic eruption (Rouwet et al. 2014). However, this type of intervention may imply severe environmental concerns due to contamination of surface lake layers with reducing, toxic deep waters (Pasche et al. 2010), suggesting that the artificial degassing approach has to be evaluated with caution.

Scientific investigations based on direct physical-chemical measurements along vertical lake profiles are thus of fundamental importance to characterize and monitor the hazardous gas reservoirs that occur in meromictic volcanic lakes.

Different methods have been used for the analysis of dissolved gases in deep lake waters 


\section{ZIMMER ET AL.}

(Tassi \& Rouwet 2014). Few of them allow data to be obtained in situ (Evans et al. 1993; Yoshida et al. 2010; Ohba et al. 2013). Most techniques also require laboratory analysis on samples collected using bottles with different geometry and equipped with various tapping systems (e.g. Niskin, Van Dorn, Ruttner samplers) or devices (single hose; Caliro et al. 2008; Tassi et al. 2009). Furthermore, the concentration of dissolved $\mathrm{CO}_{2}$ has often been determined indirectly, based on $\mathrm{pH}$ (Kusakabe et al. 2000) and alkalinity. To overcome the disadvantages related to different problems, such as tedious laboratory analysis, sampling difficulties and instrumental efficiency, an improved gas sensor device, based on a membrane technique and suitable for measurements and sampling of dissolved gases, was developed. This device is easy to handle. It operates via a wire line and is free of any complex mechanical components.

This paper provides a description of the gas membrane sensor (GMS) and its application under conditions typical for meromictic lakes hosted in volcanic systems. The Monticchio Piccolo and Monticchio Grande (southern Italy) and Pavin (France) lakes were investigated to test the reliability of this new technical approach. Concentrations of dissolved $\mathrm{CO}_{2}$ and $\mathrm{CH}_{4}$ in different water layers measured with the GMS were compared with those obtained using the single hose $(\mathrm{SH})$ method.

\section{Theoretical background}

The key component of the GMS system is a phase separating membrane often used in applied sciences (Burger et al. 1996), medicine and industry (Kesson 1984, 1985), in laboratories or otherwise protected environments for gas enrichment and separation purposes. Gas permeation through a membrane generally takes place in several steps according to the solution-diffusion model of Graham (1866). The penetrant condenses and dissolves at the surface of the membrane; then it diffuses in liquid form through the membrane under the influence of a concentration gradient (chemical potential) and evaporates to the gaseous state at the opposite surface (Klopffer \& Flaconnèche 2001).

The relation between permeability, diffusivity and solubility is, as follows:

$$
P_{o}=D_{s} \times S
$$

where $D_{\mathrm{s}}$ is the diffusivity coefficient $\left(\mathrm{cm}^{2} \mathrm{~s}^{-1}\right)$ and $S$ the solubility coefficient $\left(\mathrm{cm}_{\text {(STP) }}^{3} \mathrm{~cm}^{-3} \mathrm{~cm} \mathrm{Hg}^{-1}\right)$. For the dissolution of small gas amounts at total pressure value near atmospheric, the simple 'Law of Henry' is valid and is linearly proportional to the partial gas pressure (Scholes et al. 2008). Hence, the gas concentration inside the membrane is directly correlated to the dissolved gas concentration in the outside water. This correlation is expressed by the permeability coefficient $\left(P_{o}\right)$, a measure of the flux through the membrane, expressed in units of 'barrer' (Alter 1962). The latter parameter depends on (equation 2):

(1) the permeating gas flux through the membrane (in $\mathrm{cm}_{(\mathrm{STP})}^{3} \mathrm{~s}^{-1}$ );

(2) the membrane surface area $\left(\right.$ in $\left.\mathrm{cm}^{2}\right)$;

(3) wall thickness (in cm);

(4) partial pressure gradient (in $\mathrm{cm} \mathrm{Hg}$ ).

$$
\frac{\mathrm{cm}_{(\mathrm{STP})}^{3} \times \mathrm{cm}}{\mathrm{cm}^{2} \times \mathrm{s} \times \mathrm{cm} \mathrm{Hg}} 10^{-10}=\text { barrer }
$$

The permeation rate through a polydimethylsiloxane (PDMS) membrane depends on temperature. As it is a thermally activated process (Michaels \& Bixler 1961), the temperature dependence can be described by the Arrhenius relation, where $E_{a}$ is the apparent activation energy for the permeation process $\left(\mathrm{J} \mathrm{mol}^{-1}\right)$ consisting of the energies of diffusion and dissolution, as follows:

$$
P_{o}=P_{o}(0) \exp \left(\frac{-E_{a}}{R T}\right)
$$

where $R$ is the gas constant $\left(\mathrm{J} \mathrm{mol}^{-1} \mathrm{~K}^{-1}\right)$ and $T$ the absolute temperature (K).

Terms of $-E_{\mathrm{a}} / R$ for $\mathrm{CO}_{2}$ and $\mathrm{CH}_{4}$ with PDMS membranes are $-118 \mathrm{~K}$ and $721 \mathrm{~K}$, respectively (Ajhar 2011). These data reflect a negative temperature correlation of the $\mathrm{CO}_{2}$ permeation coefficient, in contrast to the positive $\mathrm{CH}_{4}$ permeation dependency.

Data on gas permeation rates for PDMS membranes (e.g. Robb 1968; Allen et al. 1977; Egli et al. 1984; Merkel et al. 2001; Praveen et al. 2006) are available in the literature, although real membrane material/gas systems generally show deviations from the theory due to different morphologies, polymer flexibilizers or previous history of the membrane (Staude 1992). Therefore, for the present study the permeation rates of $\mathrm{CO}_{2}$ and $\mathrm{CH}_{4}$ through the membrane tube used were determined experimentally in the laboratory by applying a thermostatic pressure device (Zimmer et al. 2011). At $7^{\circ} \mathrm{C}$, the measured $\mathrm{CO}_{2}$ and $\mathrm{CH}_{4}$ coefficients were 945 and 153 barrer, respectively.

The partial pressure of dissolved gases in the lake waters was calculated with the transformed equation (2). The conversion of the partial gas pressure into the corresponding dissolved gas concentration at the measured temperature of the lake water $\left(T\right.$ in ${ }^{\circ} \mathrm{C}$ ) was carried out according to the 


\section{MEMBRANE TECHNIQUE FOR GAS MEASUREMENTS}

Henry's law constants $\left(H_{\mathrm{i}}\right)$ of Sander (1999), whose dependencies on temperature are as follows:

$$
\begin{aligned}
H_{\mathrm{CO}_{2}}= & 0.034 \\
& \times \exp \left(2400 \times\left(\frac{1}{273.15+T}-\frac{1}{298.15}\right)\right)\left[\mathrm{moll}^{-1} \mathrm{~atm}^{-1}\right]
\end{aligned}
$$$$
H_{\mathrm{CH}_{4}}=0.0014
$$$$
\times \exp \left(1700 \times\left(\frac{1}{273.15+T}-\frac{1}{298.15}\right)\right)\left[\mathrm{moll}^{-1} \mathrm{~atm}^{-1}\right]
$$

\section{General features of the test sites}

GMS and SH measurements were carried out at the Monticchio Piccolo and Monticchio Grande lakes (MP and MG, respectively) in Italy and at Lac Pavin (LP) in France. These volcanic lakes are characterized by permanent water stratifications, with the occurrence of an anaerobic hypolimnion overlaid by an aerobic epilimnion (Lopes et al. 2011; Cabassi et al. 2013).

MG and MP are located SW of Mt Vulture in two maars formed $140 \mathrm{ka}$ ago during the last eruptive activity of Mt Vulture (Caracausi et al. 2009 and reference therein). MP has a maximum depth of $38 \mathrm{~m}$ and a surface area of $0.16 \mathrm{~km}^{2}$, whilst MG reaches a maximum depth of $35 \mathrm{~m}$ with a surface area of $0.41 \mathrm{~km}^{2}$. Dissolved $\mathrm{CH}_{4}$ in both lakes has a typical biogenic isotope signature $\left(\delta^{13} \mathrm{C}-\mathrm{CH}_{4} \leq-50 \%\right.$ o $\mathrm{V}$-PDP), whereas according to the $\delta^{13} \mathrm{C}-\mathrm{CO}_{2}$ values (MG $-4.3 \%$ and MP $-1.6 \%$ V-PDP) $\mathrm{CO}_{2}$ was interpreted as a mixture of fluids from mantle and thermometamorphic reactions involving limestone (Cabassi et al. 2013). In both lakes, water rollover events have occurred several times during the last 200 years (Caracausi et al. 2009; Cabassi et al. 2013).

LP, located at an altitude of $1197 \mathrm{~m}$ above sea level., is a maar lake formed by a phreatomagmatic eruption about 6 ka ago (Camus et al. 1993) and represents the youngest volcanic activity in the Massif Central. LP has a maximum depth of $92 \mathrm{~m}$ and a surface area of $0.44 \mathrm{~km}^{2}$. Dissolved $\mathrm{CO}_{2}$ in the hypolimnion has a dominant magmatic origin, whereas the source for $\mathrm{CH}_{4}$ is likely biogenic (AeschbachHertig et al. 1999), although the lake was classified as low-productive (Restituito 1987).

\section{Material and methods}

\section{Description of the GMS system}

The GMS system basically consists of: (1) gas analytical devices at the surface; and (2) a gas collector that is lowered to the desired water depth (Fig. 1).

The gas collector is composed of a phase-separating membrane tube, a pressure and temperature transmitter (Keller, Typ PA-36XW), a water pump (Barwig, Typ 04, $100 \mathrm{ml} \mathrm{min}^{-1}$ ) placed in a protective plastic housing, and a custom-made cable.

PDMS was chosen for the membrane tube due to the relatively high gas permeability of this material. Commercial PDMS membranes available for gas separation purposes have a thickness at the micrometre scale and are mostly stabilized by a supportive porous material. For the present study, a $0.8 \mathrm{~mm}$ thick silicon tube with a surface area of $270 \mathrm{~cm}^{2}$ was used. This type of membrane was already tested and applied as a component for $\mathrm{CO}_{2}$ analysis in deep boreholes (Zimmer et al. 2011). The cable embeds two stainless steel capillaries (inner $\phi$ of $2 \mathrm{~mm}$ ), two strain reliefs, as well as three double core wires for the power supply of the water pump and the signal transmission of the pressure and temperature sensor.

A carrier gas (Ar), provided from a 21, 100 bar pressure vessel at the surface, was introduced through the first inlet capillary into the membrane tube. The Ar flux was set at $50 \mathrm{ml} \mathrm{min}^{-1}$ at 1.2 bar using a gas flow controller (Analyt-MTC, 35829 Mass Controller) and pressure regulator (Air Liquid). As the outflow capillary is open to the atmosphere, the Ar pressure inside the membrane tube is constant and close to that of the atmosphere.

The gas pressure on the outer membrane face depends on the water depth at the measurement site. In order to resist the high-pressure gradient, the membrane tube was filled with glass spheres of 1-2 $\mathrm{mm}$ in diameter. The glass spheres prevented the membrane tube from collapsing, maintaining its form and allowing the gas to pass through. Adopting this solution, the membrane tube can resist pressures higher than $20 \mathrm{MPa}$, corresponding to a measurement site up to a depth of $2 \mathrm{~km}$ (Zimmer \& Erzinger 2009). To prevent clogging, two filters were placed between the membrane tube and the stainless steel capillaries. To avoid depletion of the gas on the membrane surface, the pump continuously circulated the lake water through the GMS housing. Via the outflow capillary, Ar and gases permeating from the lake water through the membrane tube were carried back to the surface. At the surface, the collected gases were analysed dynamically in real time using an LI 820 sensor for $\mathrm{CO}_{2}$ (LI-COR Inc.) with a measurement range between 0 and 2000 ppmv and a photoacoustic sensor (Innova 1412) for $\mathrm{CH}_{4}$ (Air Tech Instruments) with a measurement range between 0.4 and 40000 ppmv.

A laptop computer controlled the sensors and stored the signals. Two $12 \mathrm{~V} 55 \mathrm{Ah}$ accumulators provided electric energy for eight hours of continuous measurements.

The standard deviation of the method for dissolved $\mathrm{CH}_{4}$ and $\mathrm{CO}_{2}$ concentration $<1 \mathrm{mmol} \mathrm{l}^{-1}$ is $30 \%$. For higher concentrations, the standard 


\section{ZIMMER ET AL.}

(a)

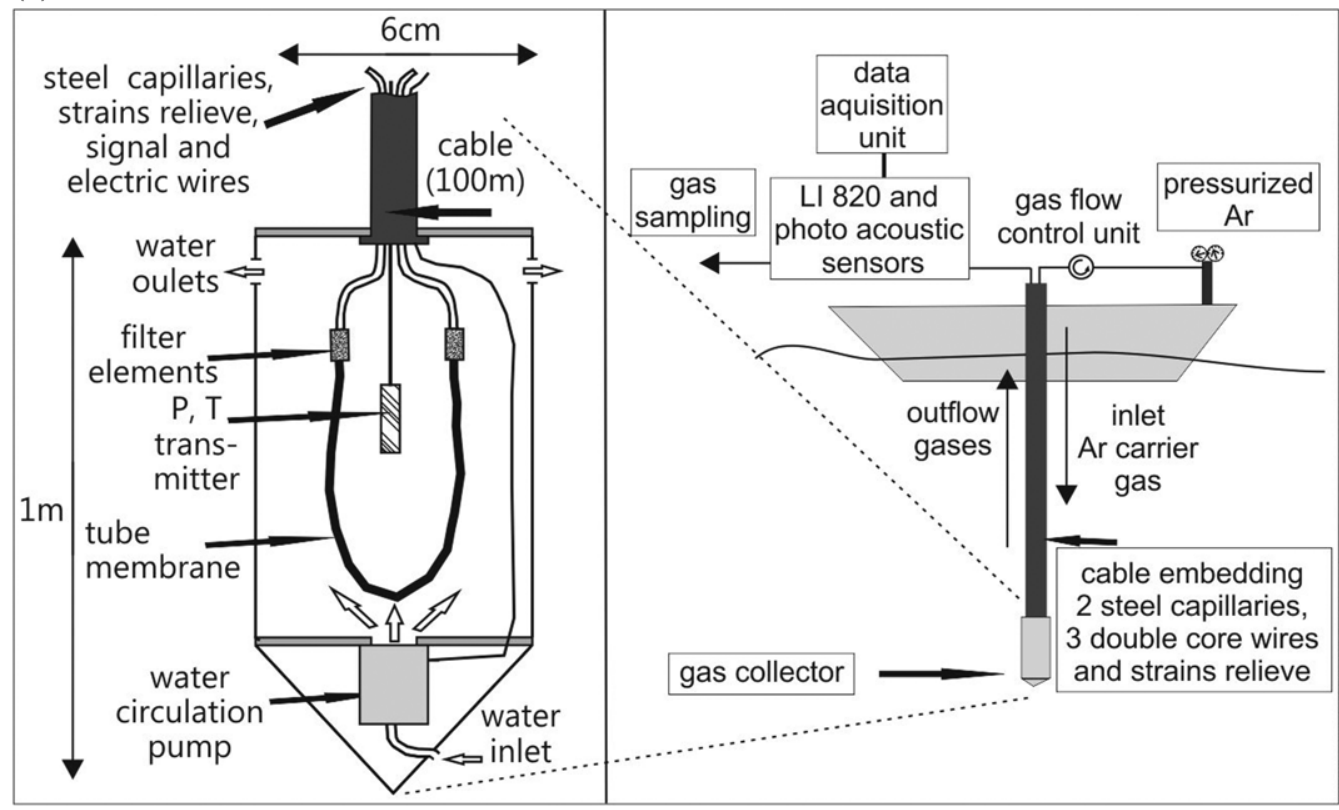

(b)

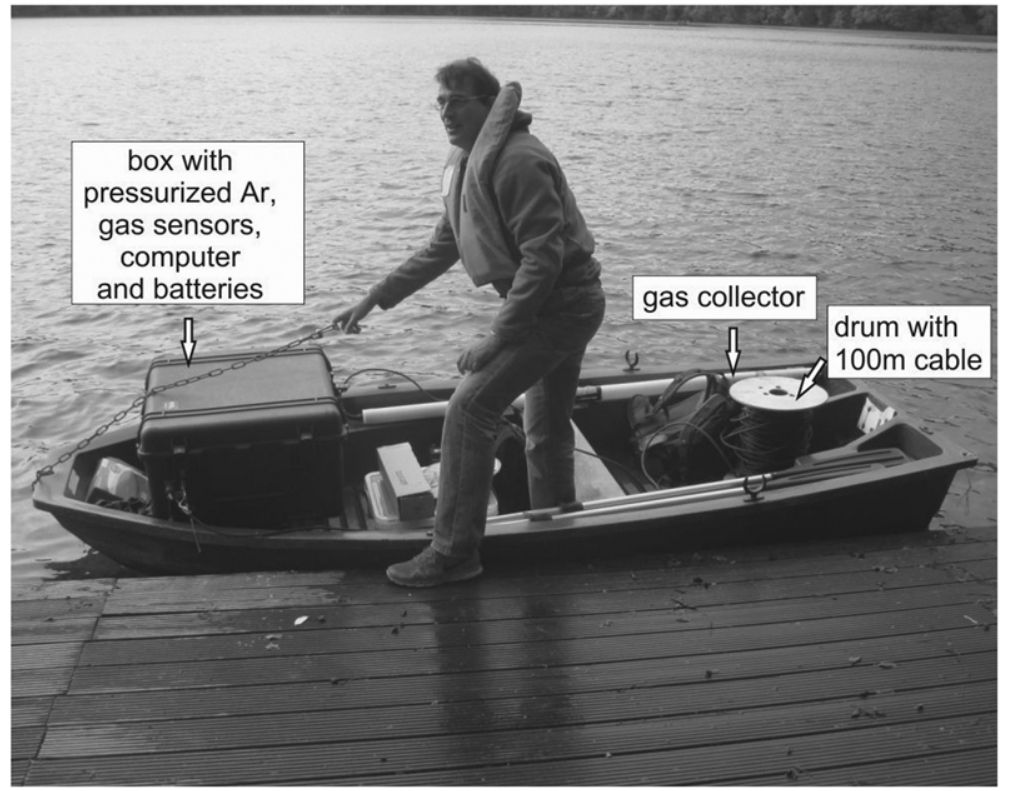

Fig. 1. Schematic representation of the GMS with gas analytical devices at the surface (b) consisting of a box with the computer, pressurized argon, gas sensors and batteries. In addition, a gas collector element (a) comprising a tube membrane, a $P, T$ transmitter, a water circulation pump and filter elements was applied under water.

deviation is $10 \%$. The higher standard deviation at lower gas concentration is a result of a larger relative impact of stochastic noise effects from several variables (e.g. electronic and thermic noise) while approaching the detection limit of the GMS method.

\section{GMS measurements}

Gas measurements in the water column were performed in the two Monticchio lakes (MP at $40^{\circ} 55^{\prime} 56.26^{\prime \prime} \mathrm{N}, 15^{\circ} 36^{\prime} 48.62^{\prime \prime} \mathrm{E}$ and $\mathrm{MG}$ at $40^{\circ}$ 


\section{MEMBRANE TECHNIQUE FOR GAS MEASUREMENTS}

$55^{\prime} 55.85^{\prime \prime} \mathrm{N}, 15^{\circ} 36^{\prime} 12.47^{\prime \prime}$ E) Italy, on 15 and 16 October 2013, respectively, while those at Lac Pavin ( $45^{\circ} 29^{\prime} 44.84^{\prime \prime} \mathrm{N}, 2^{\circ} 53^{\prime} 17.21^{\prime \prime}$ E) France, were carried out on 27 May 2014.

The sensor was manually lowered to the desired depth by the custom-made cable as the strain reliefs inside the cable take the complete weight. The sensor depth was controlled by a scale printed directly on the cable. The manual cable winding and the handling of the sensor were relatively easy due to the flexibility of the cable and the light total weight (about $12 \mathrm{~kg}$ ). The computer, analytical sensors, batteries and Ar cylinder were placed inside a single waterproof box to protect them from splashing water in the boat and for easier handling on the shore.

The GMS measurements were carried out along the vertical profiles, from $5 \mathrm{~m}$ below the lake surface down to the lake maximum depth $(\mathrm{MP}=38 \mathrm{~m}$, $\mathrm{MG}=35 \mathrm{~m}, \quad \mathrm{LP}=92 \mathrm{~m}$ ) at intervals of $5 \mathrm{~m}$. At each measurement site, the GMS remained in position for 15 minutes, i.e. until the measured gas concentration in the Ar carrier gas was stable.

\section{Temperature and SH measurements}

Water temperature $(T)$, along the vertical profiles of the MP, MG and LP lakes, was measured using a Hydrolab probe (Idroprobe) equipped with a data logger for data storage. The nominal precisions are, as follows:

$$
\text { depth, } \pm 0.05 \mathrm{~m} \text {; temperature, } \pm 0.03^{\circ} \mathrm{C} \text {. }
$$

The sampling of dissolved gases using the SH method was carried out simultaneously to the GMS measurements. The SH device consisted of $10 \mathrm{~m}$ long Rilsan tubes (inner $\phi=6 \mathrm{~mm}$ ) connected by steel joints. Once the tube end was lowered to the chosen depth, water was pumped up to the surface by means of a $150 \mathrm{ml}$ glass syringe, connected to a three-way valve, and transferred into pre-evacuated $250 \mathrm{ml}$ glass vials equipped with a Teflon stopcock after the displacement of a water volume double that of the inner volume of the tube (Tassi et al. 2009). The sampling flasks were filled with water up to three-quarters of the inner volume. The free gas phase in the flask headspace was analysed by gas chromatography using Shimadzu $14 \mathrm{a}$ and Shimadzu 15a gas chromatographs equipped with TC- and FI-detectors, respectively. The chemical composition of dissolved gases was calculated using: (1) the gas composition; (2) the pressure; (3) the volume of the flask headspace; and (4) the solubility coefficient in water of each gas compound (Tassi et al. 2009). The analytical error for the dissolved gas analyses was $\leq 5 \%$.

\section{Results and discussion}

\section{Profiles of temperature}

Water temperature vertical profiles of the investigated lakes are reported in Figure 2a-c.

MP and MG were sampled at the end of the summer season, explaining the relatively high water temperatures measured at the surface (up to $18.7^{\circ} \mathrm{C}$ and $18.2^{\circ} \mathrm{C}$, respectively). LP was sampled in spring, thus the surface water was relatively cold $\left(10.7^{\circ} \mathrm{C}\right)$. At MP (Fig. 2a), temperature decreased with increasing depth showing a clear thermocline at $7-13 \mathrm{~m}$ depth. The lowest temperature was reached at $-15 \mathrm{~m}\left(7.1^{\circ} \mathrm{C}\right)$ and then progressively increased up to $9^{\circ} \mathrm{C}$ at the lake bottom. At MG (Fig. 2b), the thermocline was at 5-9 $\mathrm{m}$ depth, whereas the minimum temperature $\left(6.6^{\circ} \mathrm{C}\right)$ was measured at the bottom. At LP, after the thermocline at $5-8 \mathrm{~m}$ depth, the temperature slightly decreased down to the minimum value $\left(3.7^{\circ} \mathrm{C}\right)$ at $25-30 \mathrm{~m}$ depth, and then increased up to $5^{\circ} \mathrm{C}$ at the lake bottom.

\section{Profiles of $\mathrm{CO}_{2}$ and $\mathrm{CH}_{4}$ concentrations}

The vertical distribution of the $\mathrm{CO}_{2}$ and $\mathrm{CH}_{4}$ concentrations at MP and MG lakes, as well as that of

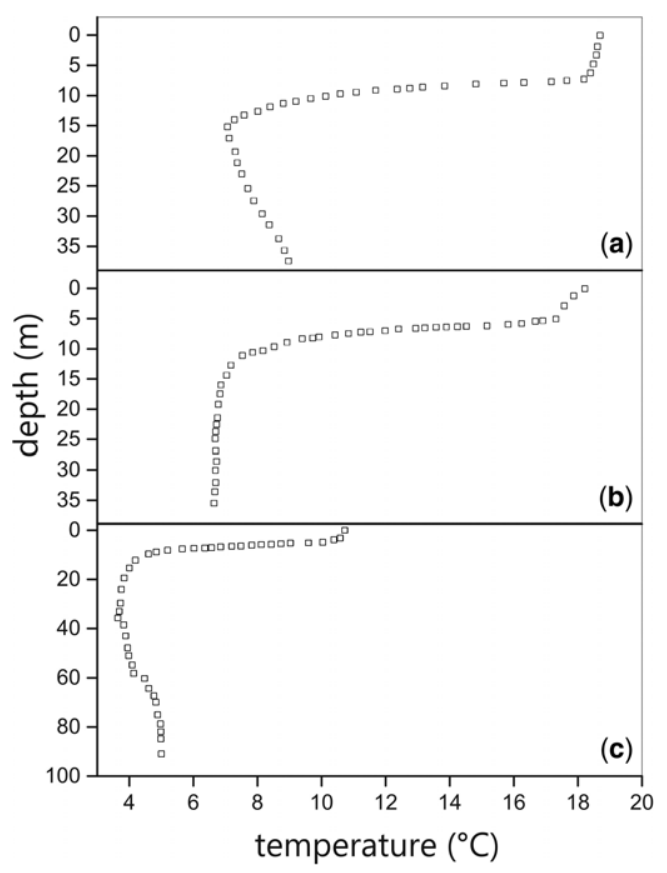

Fig. 2. Water temperature-depth profiles at (a) Monticchio Piccolo, MP, (b) Monticchio Grande, MG and (c) Pavin, LP, lakes. 
M. ZIMMER ET AL.

Table 1. Temperature and $\mathrm{CO}_{2}$ and $\mathrm{CH}_{4}$ concentrations and partial pressures measured at MP and MG using the GMS and SH methods

\begin{tabular}{|c|c|c|c|c|c|c|c|}
\hline $\begin{array}{l}\text { Depth } \\
\text { (m) }\end{array}$ & $\begin{array}{c}T \\
\left({ }^{\circ} \mathrm{C}\right)\end{array}$ & $\begin{array}{c}\mathrm{CO}_{2} \\
\left(\mathrm{mmol} \mathrm{l}^{-1}\right) \\
\mathrm{SH}\end{array}$ & $\begin{array}{c}\mathrm{CO}_{2} \\
\left(\mathrm{mmol} \mathrm{1}^{-1}\right) \\
\text { GMS }\end{array}$ & $\begin{array}{c}P_{\mathrm{CO}_{2}} \\
\text { (mbar) } \\
\text { GMS }\end{array}$ & $\begin{array}{c}\mathrm{CH}_{4} \\
\left(\mathrm{mmol} \mathrm{l}^{-1}\right) \\
\mathrm{SH}\end{array}$ & $\begin{array}{c}\mathrm{CH}_{4} \\
\left(\mathrm{mmol} \mathrm{1}^{-1}\right) \\
\text { GMS }\end{array}$ & $\begin{array}{c}P_{\mathrm{CH} 4} \\
\text { (mbar) } \\
\text { GMS }\end{array}$ \\
\hline \multicolumn{8}{|c|}{ Monticchio Piccolo } \\
\hline 0 & 18.7 & & & & & & \\
\hline 5 & 18.4 & 0.27 & 0.27 & 6.6 & 0.02 & & \\
\hline 10 & 10.2 & 0.93 & 0.98 & 19 & 0.05 & 0.04 & 21 \\
\hline 15 & 7.1 & 6.4 & 6.1 & 108 & 0.66 & 0.69 & 340 \\
\hline 20 & 7.3 & 9.2 & 9.4 & 166 & 1.05 & 1.09 & 544 \\
\hline 25 & 7.7 & 10.1 & 10.1 & 181 & 1.17 & 1.19 & 597 \\
\hline 30 & 8.2 & 11.4 & 11.1 & 202 & 1.57 & 1.54 & 784 \\
\hline 35 & 8.7 & 14.5 & 14.2 & 262 & 2.21 & 2.10 & 1078 \\
\hline 38 & 9.0 & 16.0 & 15.0 & 280 & 2.51 & 2.30 & 1187 \\
\hline \multicolumn{8}{|c|}{ Monticchio Grande } \\
\hline 0 & 18.2 & & & & & & \\
\hline 5 & 17.3 & 0.36 & 0.23 & 5.5 & 0.01 & 0.01 & 6.2 \\
\hline 10 & 8.3 & 0.71 & 0.55 & 10 & 0.11 & 0.13 & 65 \\
\hline 15 & 7.0 & 1.37 & 1.20 & 21 & 0.17 & 0.15 & 75 \\
\hline 20 & 6.8 & 2.52 & 2.12 & 37 & 0.24 & 0.26 & 128 \\
\hline 25 & 6.7 & 3.45 & 3.74 & 65 & 0.28 & 0.26 & 127 \\
\hline 30 & 6.7 & 3.74 & 3.97 & 69 & 0.37 & 0.35 & 171 \\
\hline 35 & 6.6 & 3.64 & 3.46 & 60 & 0.36 & 0.39 & 194 \\
\hline
\end{tabular}

$\mathrm{CO}_{2}$ at LP measured using both the GMS and the $\mathrm{SH}$ methods, is reported in Tables 1 and 2. $\mathrm{No} \mathrm{CH}_{4}$ measurements are available for LP due to a sensor failure. The concentrations of $\mathrm{CO}_{2}$ and $\mathrm{CH}_{4}$ at $\mathrm{MP}$ increased almost regularly with depth (Fig. 3a, b), reaching their maximum concentrations at the lake bottom (up to 15 and $2.3 \mathrm{mmol} \mathrm{l}^{-1}$ respectively; GMS method). At MG (Fig. 4a, b), the dissolved

Table 2. Temperature and $\mathrm{CO}_{2}$ concentration and partial pressure measured at LP using the GMS and SH methods

\begin{tabular}{lcccc}
\hline $\begin{array}{l}\text { Depth } \\
(\mathrm{m})\end{array}$ & $\begin{array}{c}T \\
\left({ }^{\circ} \mathrm{C}\right)\end{array}$ & $\begin{array}{c}\mathrm{CO}_{2} \\
\left(\mathrm{mmol} \mathrm{l}^{-1}\right)\end{array}$ & $\begin{array}{c}\mathrm{CO}_{2} \\
\left(\mathrm{mmol} \mathrm{l}^{-1}\right) \\
\mathrm{GMS}\end{array}$ & $\begin{array}{c}\mathrm{P}_{\mathrm{CO}_{2}} \\
(\mathrm{mbar})\end{array}$ \\
\hline $\begin{array}{l}\text { Lac Pavin } \\
0\end{array}$ & & & & \\
5 & 10.7 & $<0.01$ & $<0.01$ & 0.8 \\
10 & 10.0 & & 0.01 & 0.9 \\
15 & 4.5 & 0.01 & 0.02 & 2.6 \\
20 & 4.0 & & 0.02 & 3.4 \\
25 & 3.8 & 0.02 & 0.03 & 4.0 \\
30 & 3.7 & & 0.03 & 6.9 \\
35 & 3.7 & 0.02 & 0.39 & 6.2 \\
40 & 3.8 & & 0.39 & 11 \\
45 & 3.8 & 0.28 & 0.69 & 13 \\
50 & 4.0 & & 0.81 & 19 \\
55 & 4.0 & 0.57 & 1.18 & 32 \\
60 & 4.3 & & 1.98 & 73 \\
65 & 4.4 & 2.35 & 4.50 & 120 \\
70 & 4.5 & & 7.35 & 135 \\
75 & 4.7 & 7.10 & 8.21 & 155 \\
80 & 4.9 & & 9.43 & 164 \\
85 & 4.9 & 8.52 & 9.95 & 168 \\
90 & 5.0 & & 10.2 & \\
\hline
\end{tabular}


MEMBRANE TECHNIQUE FOR GAS MEASUREMENTS
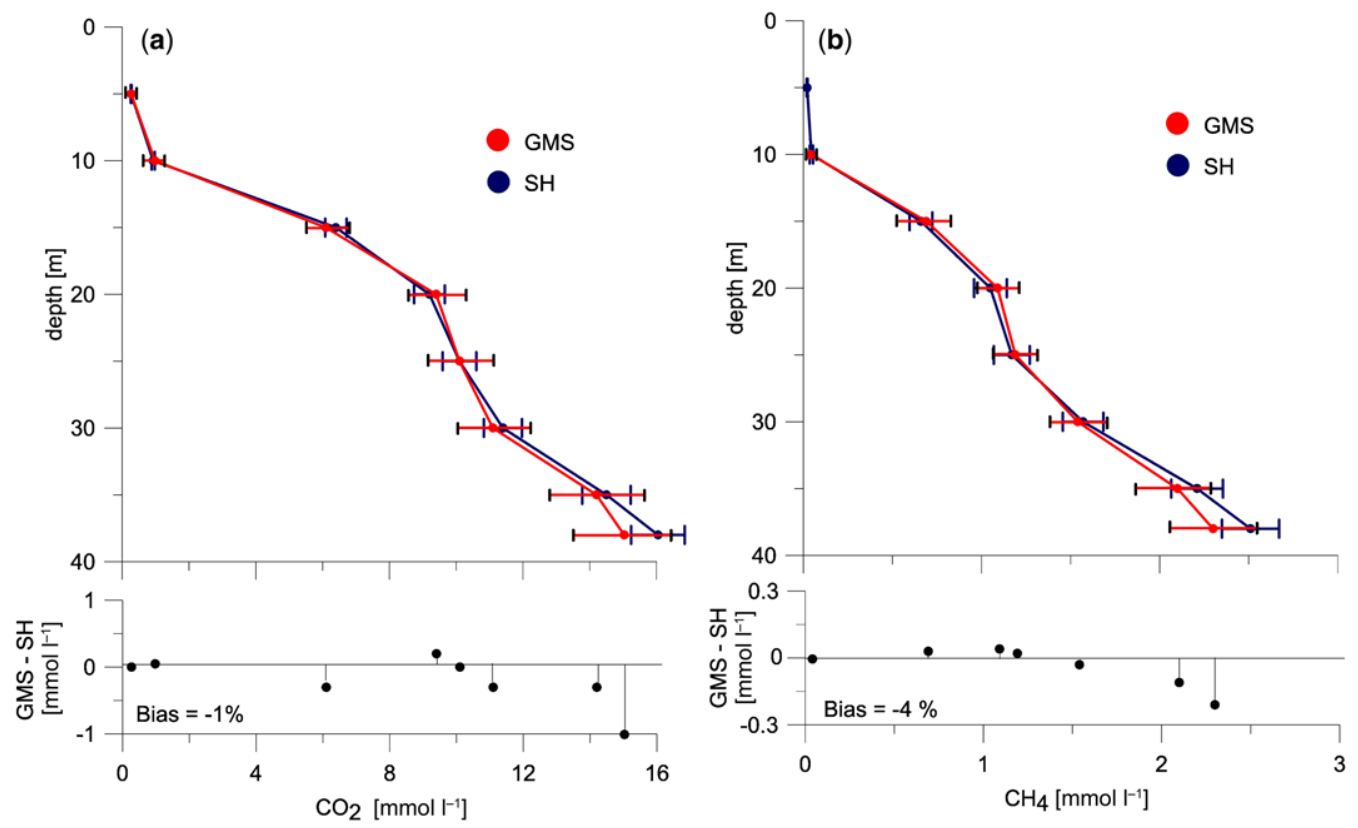

Fig. 3. (a) $\mathrm{CO}_{2}$ and (b) $\mathrm{CH}_{4}$ concentrations measured with GMS (red) and $\mathrm{SH}$ (blue) at MP. Error bars indicate the uncertainty of the GMS $\left(<1 \mathrm{mmol}^{-1} 30 \%\right.$ and $\left.>1 \mathrm{mmol}^{-1} 10 \%\right)$ and SH $(5 \%)$ results. Differences between corresponding data pairs and the relative bias $(B)$ of the GMS against the SH method are shown below.

$B=100 \% \times \sum\left(Y_{i} / X_{i}-1\right) n^{-1}$, where $Y$ is the result of the GMS system, $X$ is that of the SH method and $n$ the number of measurements.
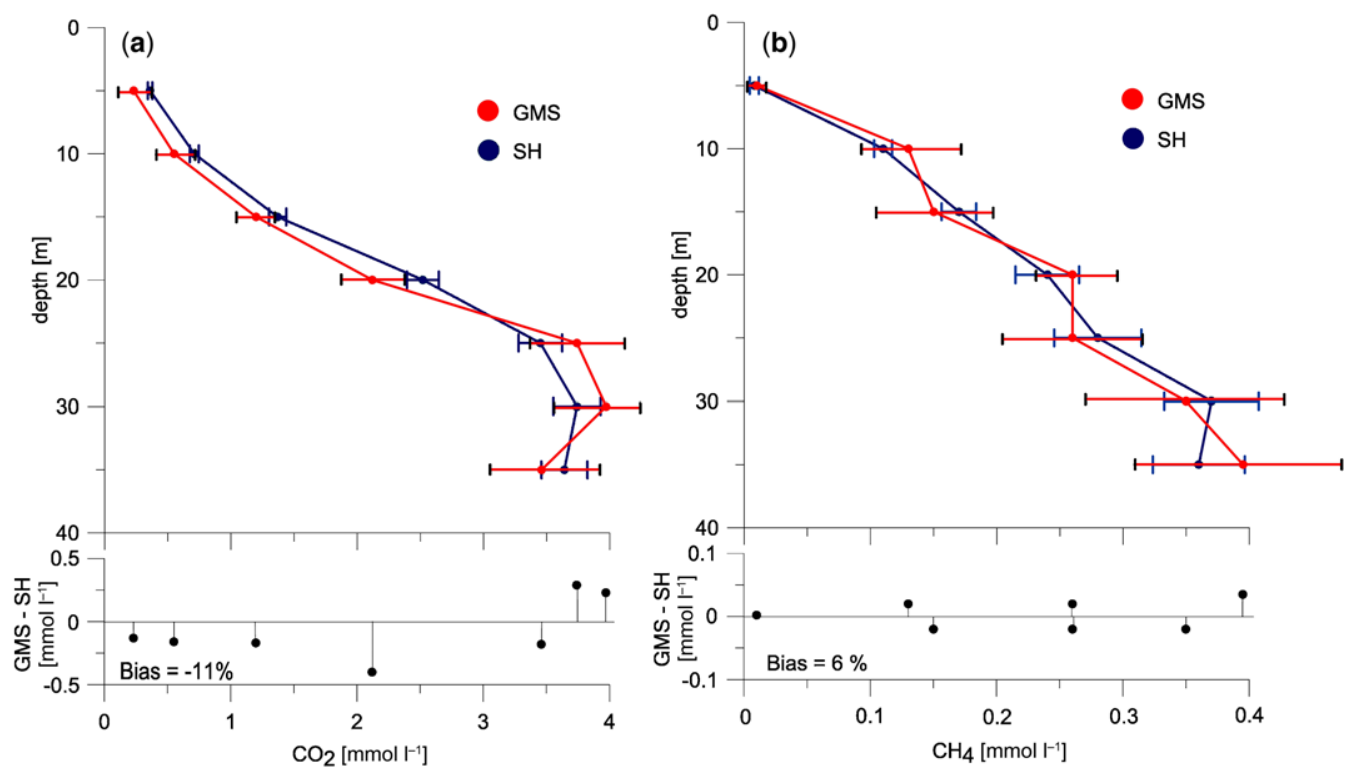

Fig. 4. (a) $\mathrm{CO}_{2}$ and (b) $\mathrm{CH}_{4}$ concentrations measured with GMS (red) and $\mathrm{SH}$ (blue) at MG. Error bars indicate the uncertainty of the GMS $\left(<1 \mathrm{mmol}^{-1} 30 \%\right.$, and $\left.>1 \mathrm{mmol}^{-1} 10 \%\right)$ and SH $(5 \%)$ results. Differences between corresponding data pairs and the relative bias $(B)$ of the GMS against the SH method are shown below. 


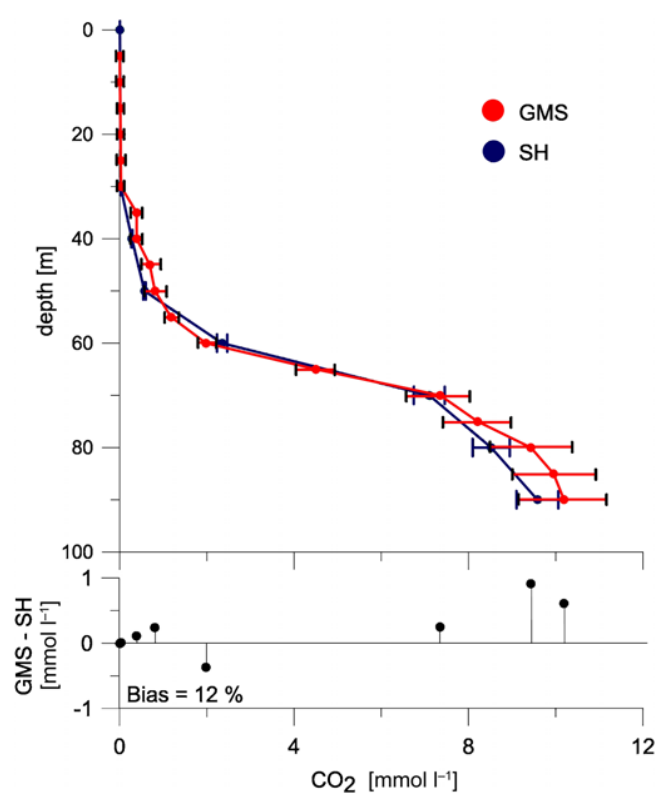

Fig. 5. $\mathrm{CO}_{2}$ concentrations measured with GMS (red) and $\mathrm{SH}$ (blue) at LP. Error bars indicate the uncertainty of the GMS $\left(<1 \mathrm{mmol} \mathrm{l}^{-1} 30 \%\right.$, and $>1 \mathrm{mmol}^{-1}$ $10 \%)$ and $\mathrm{SH}(5 \%)$ results. Differences between corresponding data pairs and the relative bias $(B)$ of the GMS against the SH method are shown below.

gas profiles were less regular, being characterized by a maximum for both gases at $30 \mathrm{~m}$ depth $\left(\mathrm{CO}_{2}\right.$ and $\mathrm{CH}_{4}, 3.97$ and $0.37 \mathrm{mmol} \mathrm{l}^{-1}$, respectively; GMS method). The dissolved gas composition of $\mathrm{MG}$, as well as the $\mathrm{CO}_{2}$ profile of MP, is consistent with that measured using the $\mathrm{SH}$ method in October 2010 (Cabassi et al. 2013). The maximum $\mathrm{CO}_{2}$ concentration in LP was $10.2 \mathrm{mmol} \mathrm{l}^{-1}$ (GMS method) at the lake bottom (Fig. 5). Literature data for dissolved $\mathrm{CO}_{2}$ in LP vary considerably as they range from 1.1 (Lehours et al. 2005) to $16 \mathrm{mmol}^{-1}$ (Aeschbach-Hertig et al. 1999). These data, which were consistent with those measured in the present study, seem to indicate that the stratification of LP was affected by significant perturbations, although no degassing of the lake was reported since 1999.

\section{Statistical comparison between the GMS and SH methods}

The relative biases $(B)$ of the GMS v. the SH data range from $-1 \%$ for $\mathrm{CO}_{2}$ in MP to $12 \%$ for $\mathrm{CO}_{2}$ in LP and are within the analytical error of the method (Figs 3-5). The relative root mean square deviation (RMSD) of the GMS measurements based on the possible bias and the uncertainty of the $\mathrm{SH}$ results is $0.37 \mathrm{mmol}^{-1}$ for $\mathrm{CO}_{2}$ and $0.07 \mathrm{mmol} \mathrm{l}^{-1}$ for $\mathrm{CH}_{4}$.

\section{Conclusions}

In this study an innovative methodological approach, the GMS technique, was used to measure the concentrations of selected gas species $\left(\mathrm{CO}_{2}\right.$ and $\mathrm{CH}_{4}$ ) dissolved in three volcanic lakes from Italy and France that are characterized by permanent or semi-permanent stratification. The compositional data obtained for the Monticchio Piccolo, Monticchio Grande and Pavin lakes by GMS were in good agreement with those measured using the SH method, indicating that the accuracy of the GMS technique is at least comparable with that of one of the most common sampling and analytical methods for the measurements of dissolved gases in a lake water column. The statistical tests have shown that the two series of data cannot be distinguished, since the corresponding data pairs overlap within the analytical uncertainties of the two methods. However, at lower dissolved gas concentrations, the consistency between the GMS and SH data decreased, possibly due to a higher standard deviation of the GMS method. To improve the sensitivity of the GMS method, the thickness of the membrane can be reduced and its surface area can be increased. These structural modifications should be able to increase both the permeation rate and the 'lake gas concentration' in the carrier gas, reducing the analytical uncertainty at low gas concentrations.

It is worth noting that the GMS method is able to deliver data on the dissolved gas concentration at any depth in a volcanic lake. Similar information is of fundamental importance for monitoring the evolution of a deep gas reservoir, which potentially represents the risk of limnic eruptions. Furthermore, by applying additional analytical devices at the surface (e.g. mass spectrometer, gas chromatograph, radon detector), the number of detectable dissolved components in the lake water can be extended to all dissolved gases. For example, GMS measurements combined with a quadrupole mass spectrometer have already provided useful data for dissolved $\mathrm{H}_{2}, \mathrm{~N}_{2}, \mathrm{O}_{2}, \mathrm{CH}_{4}$ and $\mathrm{CO}_{2}$ in drilling fluids of deep boreholes (Zimmer et al. 2011). Real-time production of compositional data is suitable for mapping large lake areas in a relatively short time and allows for the construction of very detailed (at depth intervals in the order of fraction of metres) vertical profiles of dissolved gas concentrations. A high number of compositional measurements at different depths and locations may be used to construct a 3D map of gas distribution, possibly helping to locate inflows of volcanic gas discharging from deep sources. 


\section{MEMBRANE TECHNIQUE FOR GAS MEASUREMENTS}

A GMS sensor could also be installed at one specific location at a certain lake depth. Maintenance of the system (replenishment of the Ar carrier gas, recalibration of the gas analytical devices) can be performed without pulling the sensor back to the lake surface.

With this method, it is also possible to obtain and collect gases from deep water layers for further geochemical and isotope studies in the laboratory. All in all, GMS can be considered a reliable and effective alternative method to traditional sampling techniques for gas concentrations in volcanic lakes.

Many thanks are due to Luciano Giannini for his assistance during the sampling session at Pavin Lake. Pierre Lavina and Didier Jézéquel are gratefully acknowledged for the logistic support and their useful suggestions before sailing on Lac Pavin. The authors are also indebted to Kathleen Lavin for her valuable editing of language and style.

\section{References}

Aeschbach-Hertig, W., Hofer, M., Kipfer, R., ImboDEN, D.M. \& WIELER, R. 1999. Accumulation of mantle gases in a permanently stratified volcanic lake (Lac Pavin, France). Geochimica et Cosmochimica Acta, 63, 3357-3372.

AJHAR, M. 2011. Membrane-based removal of volatile methylsiloxanes from biogas. $\mathrm{PhD}$ thesis, RWTH Aachen.

Allen, S.M., Fujil, M., Stannett, V., Hopfenberg, H.B. \& Williams, J.L. 1977. The barrier properties of polyacrylonitrile. Journal of Membrane Science, 2, $153-164$

Alter, H. 1962. A critical investigation of polyethylene gas permeability. Journal of Polymer Science, 57, 925-935.

Burger, B.V., Burger, W.J.G. \& Burger, I. 1996. Trace determination of volatile organic compounds in water using permeation through a hollow fibre membrane and carrier gas stripping. Journal of High Resolution Chromatography, 19, 571-576.

Cabassi, J., Tassi, F. et al. 2013. Biogeochemical processes involving dissolved $\mathrm{CO}_{2}$ and $\mathrm{CH}_{4}$ at Albano, Averno, and Monticchio meromictic volcanic lakes (Central-Southern Italy). Bulletin of Volcanology, 75, 683 .

CABassi, J., Tassi, F. ET AL. 2014. Geosphere-biosphere interactions in Bio-Activity volcanic lakes: evidences from Hule and Rio Cuarto (Costa Rica). PloS ONE, 9, e102456, 1-26.

Caliro, S., Chiodini, G., Izzo, G., Minopoli, C., SignoRini, A., Avino, R. \& Granieri, D. 2008. Geochemical and biochemical evidence of lake turnover and fish kill at Lake Averno, Italy. Journal of Volcanology and Geothermal Research, 178, 305-316.

Camus, G., Michard, G. et al. 1993. Bulletin de la Société Géologique de France, 164, 767-781.

Caracausi, A., Nuccio, P.M., Favara, R., Nicolosi, M. \& Paternoster, M. 2009. Gas hazard assessment at the Monticchio crater Lakes of Mt. Vulture, a volcano in Southern Italy. Terra Nova, 21, 83-87.

Delmelle, P. \& Bernard, A. 2000. Volcanic lakes. In: Sigurdsson, H., Houghton, B., McNutt, S.R., RYMER, H. \& STIX, J. (eds) Encyclopedia of Volcanoes. Academic Press, San Diego, p. 877-895.

EgLI, S., RuF, A. \& Buck, A. 1984. Gastrennung mittels Membranen - Ein Überblick. Swiss Chem., 6, 89-122.

Evans, W.C., Kling, G.W., Tuttle, M.L., Tanyileke, G. \& White, L.D. 1993. Gas buildup in Lake Nyos, Cameroon: the recharge process and its consequences. Applied Geochemistry, 8, 207-221.

Graham, T. 1866. Ueber die Absorption und dialytische Trennung der Gase mittelst colloidaler Diaphragmen. Polytechnisches Journal, 182, 307-309.

Halbwachs, M., Sabroux, J.C. ET AL. 2004. Degassing the 'killer lakes' Nyos and Monoun, Cameroon. EOS, 85, 281-288.

KEsson, J. 1984. The diffusion of gases through a silicon rubber membrane, and its application to an in-line carbonation meter. MBAA Technical Quarterly, 21, $143-146$.

Kesson, J. 1985. Method of and apparatus for monitoring concentration of gas in a liquid. US Patent 4,550,590.

Kling, G.W., Clark, M.A. ET AL. 1987. The 1986 Lake Nyos gas disaster in Cameroon, West Africa. Science, 236, 169-175.

Kling, G.W., Evans, W.C., Tanyileke, G., Kusakabe, M., Ohba, T., Yoshida, Y. \& Hell, J.V. 2005. Degassing Lakes Nyos and Monoun: defusing certain disaster. Proceedings of the National Academy of Sciences of the USA, 102, 14 185-14 190.

KlopfFer, M.H. \& Flaconnèche, B. 2001. Transport properties of gases in polymers: bibliographic review. Oil \& Gas Science and Technology - Rev. IFP, 56, 223-244.

KusaKabe, M. 1996. Hazardous crater lakes. In: SCARPA, R. \& Tilling, R.I. (eds) Monitoring and Mitigation of Volcano Hazards. Springer, Berlin, 573-598.

Kusakabe, M., Tanyileke, G., McCord, S.A. \& Schladow, S.G. 2000. Recent $\mathrm{pH}$ and $\mathrm{CO}_{2}$ profiles at Lakes Nyos and Monoun, Cameroon: implications for the degassing strategy and its numerical simulation. Journal of Volcanology and Geothermal Research, 97, 241-260.

Kusakabe, M., OBha, T. et AL. 2008. Evolution of $\mathrm{CO}_{2}$ in Lakes Monoun and Nyos, Cameroon, before and during controlled degassing. Geochemical Journal, 42, 93-118.

Lehours, A.-C., Bardot, C., Thenot, A., Debroas, D. \& FonTy, G. 2005. Anaerobic microbial communities in lake pavin, a unique meromitic lake in France. Applied and Environmental Microbiology, 71, 7389-7400.

LOPES, F., Violler, E. ET AL. 2011. Biogeochemical modeling of anaerobic $\mathrm{v}$. aerobic methane oxidation in a meromitic crater lake (Lake Pavin, France). Applied Geochemistry, 26, 1919-1932.

Merkel, T.C., Gupta, R.P., Turk, B.S. \& Freeman, B.D. 2001. Mixed-gas permeation of syngas components in poly(dimethylsiloxane) and poly(1-trimethylsilyl-1propyne) at elevated temperatures. Journal of Membrane Science, 191, 85-94. 


\section{ZIMMER ET AL.}

Michaels, A.S. \& Bixler, H.J. 1961. Flow of gases through polyethylene. Journal of Polymer Science, $\mathbf{L}$, $413-439$.

OHBA, T. ET AL. 2013. Contribution of methane to total gas pressure in deep waters at lakes Nyos and Monoun (Cameroon, West Africa.). Geochemical Journal, 47, 349-362.

Pasche, N., Alunga, G. ET AL. 2010. Abrupt onset of carbonate deposition in Lake Kivu during the 1960s: response to recent environmental change. Journal of Paleolimnology, 44, 931-946.

Pasternack, G.B. \& VAreKamP, J.C. 1997. Volcanic lake systematic I. Physical constraints. Bulletin of Volcanology, 58, 528-538.

Praveen, J., Mason, L.W. \& Way, J.D. 2006. Characterization of silicone rubber membrane materials at low temperature and low pressure conditions. Journal of Membrane Science, 272, 125-136.

Restituito, F. 1987. Consequences of redox conditions on the distribution of cations in a meromictic oligotrophic lake. Hydrobiologia, 144, 63-75.

RoвB, W.L. 1968. Thin silicone membranes - their permeation properties and some applications. Annals of the New York Academy of Sciences, 146, 119-137.

Rouwet, D., Tassi, F., Mora-Amador, R., SAndri, L. \& Chiarini, V. 2014. Past, present and future of volcanic lake monitoring. Journal of Volcanology and Geothermal Research, 272, 78-97.

Sabroux, J.C., Dubois, E. \& Doyotte, C. 1987. The limnic eruption: a new geological hazard? Paper presented at the International Scientific Congress on Lake Nyos Disaster, 16-20 March, Younde, Cameroon.

SANDER, R. 1999. Compilation of Henry's Law Constants for Inorganic and Organic Species of Potential Importance in Environmental Chemistry. Max-Planck Institute of Chemistry, Germany, http://www.mpchmainz.mpg.de/ sander/res/henry.html
Scholes, C.A., Kentish, S.E. \& Stevens, G.W. 2008. Carbon dioxide separation through polymeric membrane systems for flue gas applications. Recent Patents on Chemical Engineering, 1, 52-66.

Sigurdsson, H., Devince, J.D., Tchoua, F.M., Presser, T.S., Pringle, M.K.W. \& Evans, W.C. 1987. Origin of the lethal gas burst from Lake Monoun, Cameroon. Journal of Volcanology and Geothermal Research, 31, $1-16$.

Simkin, T. \& Sieber, L. 1994. Volcanoes of the World: A Regional Directory, Gazetteer, and Chronology of Volcanism During the Last 10,000 Years. Geoscience, Tucson.

Staude, E. 1992. Membranen und Membranprozesse. $\mathrm{VCH}$, Weinheim.

TAssi, F. \& Rouwet, D. 2014. Geochemical studies of Nyos-type lakes: different approaches for data production and interpretation. An overview. Journal of Limnology, 73, 39-54.

TASSI, F., VASElli, O. ET AL. 2009. Water and gas chemistry at Lake Kivu (DRC): geochemical evidence of vertical and horizontal heterogeneities in a multibasin structure. Geochemistry, Geophysics, Geosystems, 10, Q02005.

Yoshida, Y., Kusakabe, M., Satake, H. \& Ohba, T. 2010. An efficient method for measuring $\mathrm{CO}_{2}$ concentration in gassy lakes: application to Lakes Nyos and Monoun, Cameroon. Geochemical Journal, 44, $441-448$.

Zimmer, M. \& ERZINGER, J. 2009. Gas membrane sampling device and gas sensor device for geological investigations. US Patent 7,523,680 B2.

Zimmer, M., Erzinger, J. \& Kujawa, C., CO2-SinK GROUP 2011. The gas membrane sensor (GMS): a new method for gas measurements in deep boreholes applied at the CO2SINK site. International Journal of Greenhouse Gas Control, 5, 995-1001. 